\title{
Valorization of wood shavings waste for the production of wood particulate composites
}

Douglas Lamounier Faria ${ }^{1}$, Thamirys Andrade Lopes ${ }^{2}$, Lourival Marin Mendes ${ }^{1}$, José Benedito Guimarães Júnior ${ }^{3}$

\footnotetext{
${ }^{1}$ Federal University of Lavras, Department of Forest Science, POB 3037, CEP: 37200-000, Lavras, MG, Brasil.

${ }^{2}$ Federal University of Viçosa, Department of Forest Science, CEP: 36570-000, Viçosa, MG, Brasil

${ }^{3}$ Federal University of Lavras, Department of Engineering, POB 3037, CEP: 37200-000, Lavras, MG, Brasil. e-mail: douglas.lamounier@yahoo.com, lourrivall@ufla.br, thamiryscpo@hotmail.com,jose.guimaraes@ufla.br
}

\begin{abstract}
The aim of this work was to evaluate the physical and mechanical properties of particleboards using particles from wood shaving at three urea-formaldehyde adhesive contents: 6,9 and $12 \%$ (dry mass basis). The particleboards were produced with nominal density of $0.70 \mathrm{~g} . \mathrm{cm}^{-3}$, pressing cycle with temperature of $160{ }^{\circ} \mathrm{C}$, pressure of $3.92 \mathrm{MPa}$ and time of 8 minutes. The properties of water absorption (WA), thickness swelling (TS), both after 2 and 24 hours, apparent density, compression ratio, perpendicular traction, modulus of elasticity (MOE) and modulus of rupture (MOR) in static bending, Janka hardness and screw withdrawal resistance were evaluated. The results of the tests indicated that with the increase of the adhesive content from 6 to $12 \%$, there was no significant statistical difference for the average values of apparent density and compression ratio, being 0.621 g.cm ${ }^{-3}$ and 1.234, respectively, and the WA and the TS are decreased after 2 and 24 hours. There was a gain of $93 \%$ for the MOR property and $64 \%$ for the MOE property with the increase of the adhesive content. For perpendicular traction, the highest mean value was $0.67 \mathrm{MPa}$, referring to the panels with $12 \%$ of adhesive. For Janka hardness, the treatments with contents of 9 and $12 \%$ of adhesive presented the highest average values being of 21.60 and $25.26 \mathrm{MPa}$, respectively. In general, the use of wood shavings is feasible for the production of particleboards with a $12 \%$ adhesive content.
\end{abstract}

Keywords: Mechanical resistance; Dimensional stability; Particleboards.

\section{INTRODUCTION}

Problems related to environmental issues such as pollution and waste generation and their consequences are in many cases associated with production processes. The better use of raw materials, through processes that incorporate the principles of environmental management, has been gaining importance in industries and research institutions, because, in addition to environmental and social benefits, it brings economic advantages to companies [1].

The lumber production process generates a large volume of residues and leftovers resulting from the transformation of the logs by the resaws and that, added to the branches, trunks and roots that remain in the forest, indicate a significantly higher volume than the wood product obtained. The residues produced in the pitsawing stage can be sawmill or saw dust, wood pieces, trimming residues, shavings, chips or top cut and bark [2].

The companies in the planted tree sector adopt the practice of rigorous management of solid waste from their activities, aiming at reducing generation, ensuring the correct destination and meeting the legal and certification requirements related to the subject. In 2016, the sector generated 47.8 million tons of solid waste, of which 33.7 million (70.5\%) were generated by forest activities and 14.1 million (29.5\%) by industrial [3].

The reuse of these residues for the manufacture of particleboards can become an alternative in an attempt to mitigate environmental impacts, as well as adding value to it, becoming a new source of raw material.

There are some works in the literature that employ waste for the manufacture of wood panels. Rios [4] evaluated the potential of cork extracted from the trunk of Kielmeyera coriacea, for the production of particleboards, which resulted in low density panels, widely used in wall lining and insulation. Mendes et al. [5] evaluated the incorporation of roller wood from the lamination of logs in the production of particleboards, obtaining good results. Lopes et al. [6] evaluated the effect of different panel densities on the physical-mechanical properties of particleboards produced with shavings. 
Given the above, the objective of this work was to evaluate the physical and mechanical properties of wood particleboards using shavings from the boarding process at three levels of urea-formaldehyde adhesive, 6,9 and $12 \%$.

\section{MATERIALS AND METHODS}

\subsection{Obtaining of material}

The shavings used to make the particleboards were used after the wood processing in the boarding stage of Eucalyptus grandis boards. The wood that generated the wood shavings had a basic density of $0.503 \pm 0.079 \mathrm{~g}_{\mathrm{cm}} \mathrm{cm}^{-3}$. The adhesive used was urea formaldehyde, which presented $60 \%$ solids content, viscosity of $200.95 \mathrm{cP}, \mathrm{pH}$ of 8.45 and timer gel of $7.85 \mathrm{~min}$.

The shavings were sifted into 9.5 to $16 \mathrm{~mm}$ aperture meshes to eliminate fines and obtain shavings with dimensions around $12 \times 8 \times 1 \mathrm{~mm}$ (length $\mathrm{x}$ width $\mathrm{x}$ thickness). Subsequently, the particles were placed in an oven at a temperature of $70 \pm 2{ }^{\circ} \mathrm{C}$ until reaching a moisture content of $5 \%$ (dry mass basis) and then weighed for the production of the panels.

\subsubsection{Manufacture of particleboards}

The panels were produced with dimensions of $300 \times 300 \times 15 \mathrm{~mm}$ and nominal density of $0.70 \mathrm{~g}^{\mathrm{cm}} \mathrm{cm}^{-3}$, with three different treatments with variations of 6,9 and $12 \%$ in the percentage of adhesive being evaluated. Each treatment had three repetitions, totaling 9 panels.

The panels were pressed at a temperature of $160^{\circ} \mathrm{C}$ and specific pressure of $3.92 \mathrm{MPa}$ for eight minutes. After pressing, the panels were placed in a climate chamber at a temperature of $20 \pm 3{ }^{\circ} \mathrm{C}$ and a relative moisture of $65 \pm 5 \%$ until reaching an equilibrium moisture of approximately $12 \%$ and the end of the adhesive solidification process.

\subsubsection{Analysis of physical and mechanical properties of particleboards}

The compression ratio of each particleboard was calculated by the ratio of the apparent density of the panel to the basic density of Eucalyptus grandis wood.

For the evaluation of water absorption properties after 2 and 24 hours of immersion (WA2h and WA24h) and thickness swelling after 2 and 24 hours (TS2h and TS24h) of immersion, the D-1037 [7] standard was employed. For the properties of modulus of rupture (MOR) and modulus of elasticity (MOE) at static bending, the standard DIN-52362 [8] was used. Perpendicular traction was assessed according to the guidelines of NBR 14810-3 [9]. The Janka hardness of particleboards was evaluated based on the D-143-94 standard [10] for solid wood, and the screw pullout strength was determined following the guidelines of NBR 14810-2 [11]. The apparent density of the panels was determined by the average density of each of the specimens used in the evaluation of the physical and mechanical properties.

For a better visualization of the adhesion occurred in the panels, $0.75 \mathrm{x}$ magnification images were made through the SMZ 1500 (Nikon) stereoscopic microscope.

\subsubsection{Statistical analysis of data}

The data were analyzed considering a completely randomized design, being submitted to analysis of variance (ANOVA) and regression, both at $5 \%$ of significance, for the mechanical and water absorption and thickness swelling tests. To evaluate the apparent density, compaction ratio and moisture properties, the data were submitted to analysis of variance (ANOVA) and Scott-Knott test, both at 5\% significance. The data were processed in the Sisvar software. 


\section{RESULTS}

\subsection{Physical properties of panels}

Table 1: presents the average values of apparent density, compression ratio and moisture of the particleboard produced.

\begin{tabular}{c|c|c|c}
\hline Adhesive (\%) & Apparent density $\mathbf{( g . \mathbf { c m } ^ { - 3 } )}$ & Compression ratio & Moisture (\%) \\
\hline $6 \%$ & $0.608 \pm 0.05 \mathrm{~A}$ & $1.217 \pm 0.07 \mathrm{~A}$ & $8.36 \pm 0.03 \mathrm{~A}$ \\
\hline $9 \%$ & $0.612 \pm 0.08 \mathrm{~A}$ & $1.225 \pm 0.05 \mathrm{~A}$ & $8.33 \pm 0.12 \mathrm{~A}$ \\
\hline $12 \%$ & $0.621 \pm 0.04 \mathrm{~A}$ & $1.234 \pm 0.04 \mathrm{~A}$ & $8.44 \pm 0.05 \mathrm{~A}$ \\
\hline
\end{tabular}

Means followed by the same letter in the same column do not differ by the Scott-Knoott test at $5 \%$ significance.

\subsection{Panels Water absorption (WA) and Thickness swelling (TS)}

The regression model adjusted for increasing the percentage of urea-formaldehyde adhesive for water absorption values 2 and 24 hours of water immersion are shown in Figure 1.

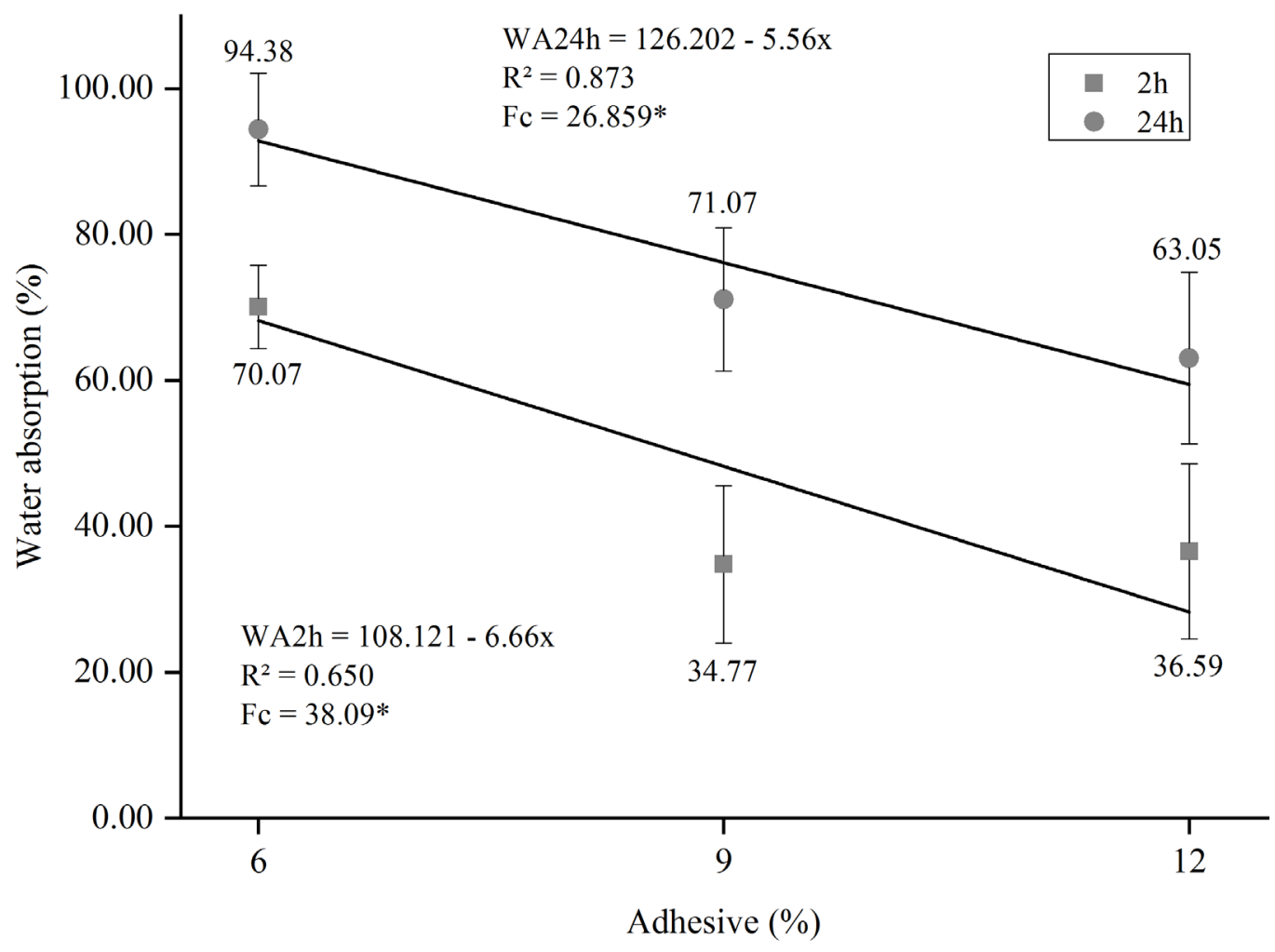

Figure 1: Water absorption after 2 and 24 hours of immersion of the particleboards, where $(*)$ - significant at $5 \%$ significance level.

Significant statistical difference was observed between the treatments for the evaluated properties. As the adhesive levels in the panels increased, they showed lower values for WA after 2 and $24 \mathrm{~h}$. This behavior can be explained by the greater adhesive distribution in the panel particles (Figure 2), resulting in lower porosity panels. 


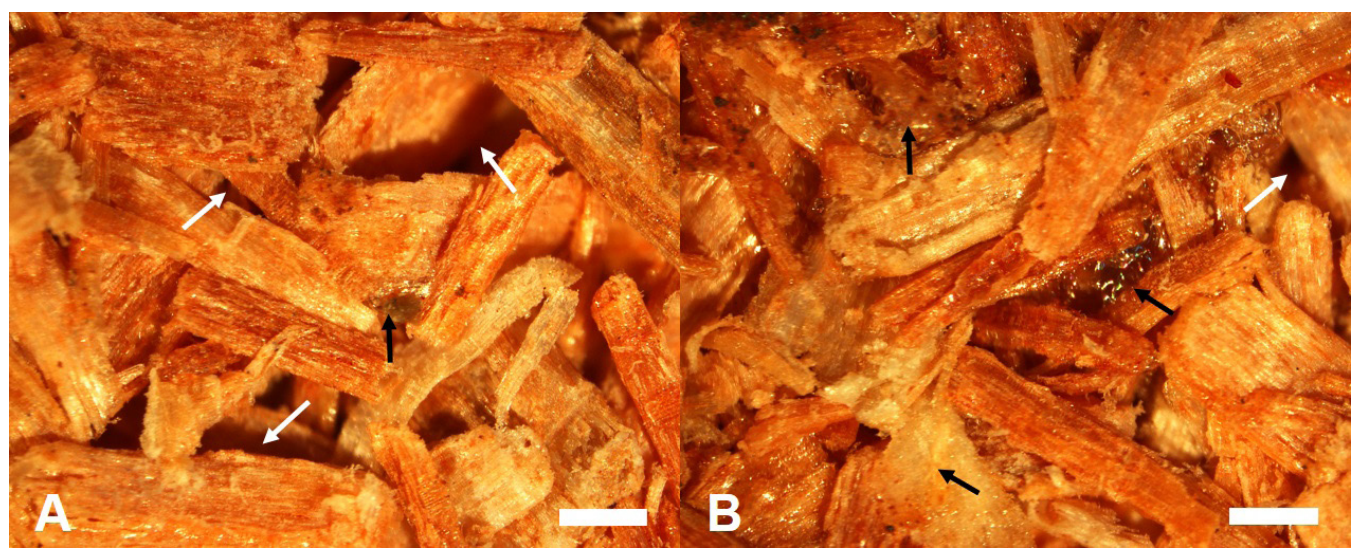

Figure 2: Particleboard produced with urea-formaldehyde adhesive. A) Particleboard produced with $6 \%$ adhesive; B) Particleboard produced with $12 \%$ adhesive. Blanks (white arrow), adhesive (black arrow). Scale bar: A-B $=500 \mu \mathrm{m}$.

The regression model adjusted for increasing the percentage of urea-formaldehyde adhesive for thickness swelling values after 2 and 24 hours of water immersion are shown in Figure 3.

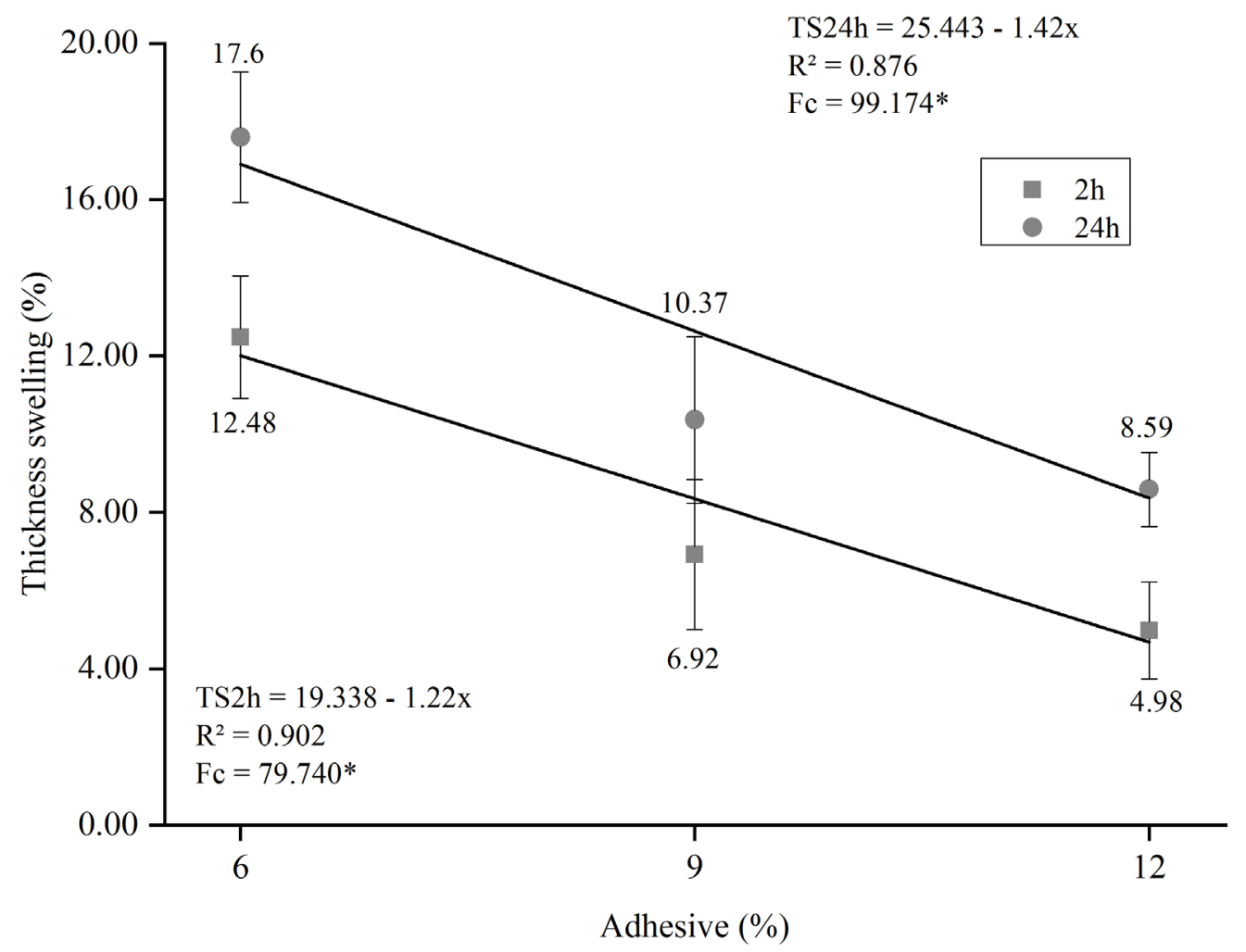

Figure 3: Thickness swelling after 2 and 24 hours of immersion of the particleboard, where $(*)$ - significant at $5 \%$ significance level.

\subsection{Mechanical characterization of panels}

\subsubsection{Static bending and perpendicular traction}

The regression model adjusted for increasing the percentage of urea-formaldehyde adhesive for the values of MOR and MOE are shown in Figures 4 and 5, respectively. 


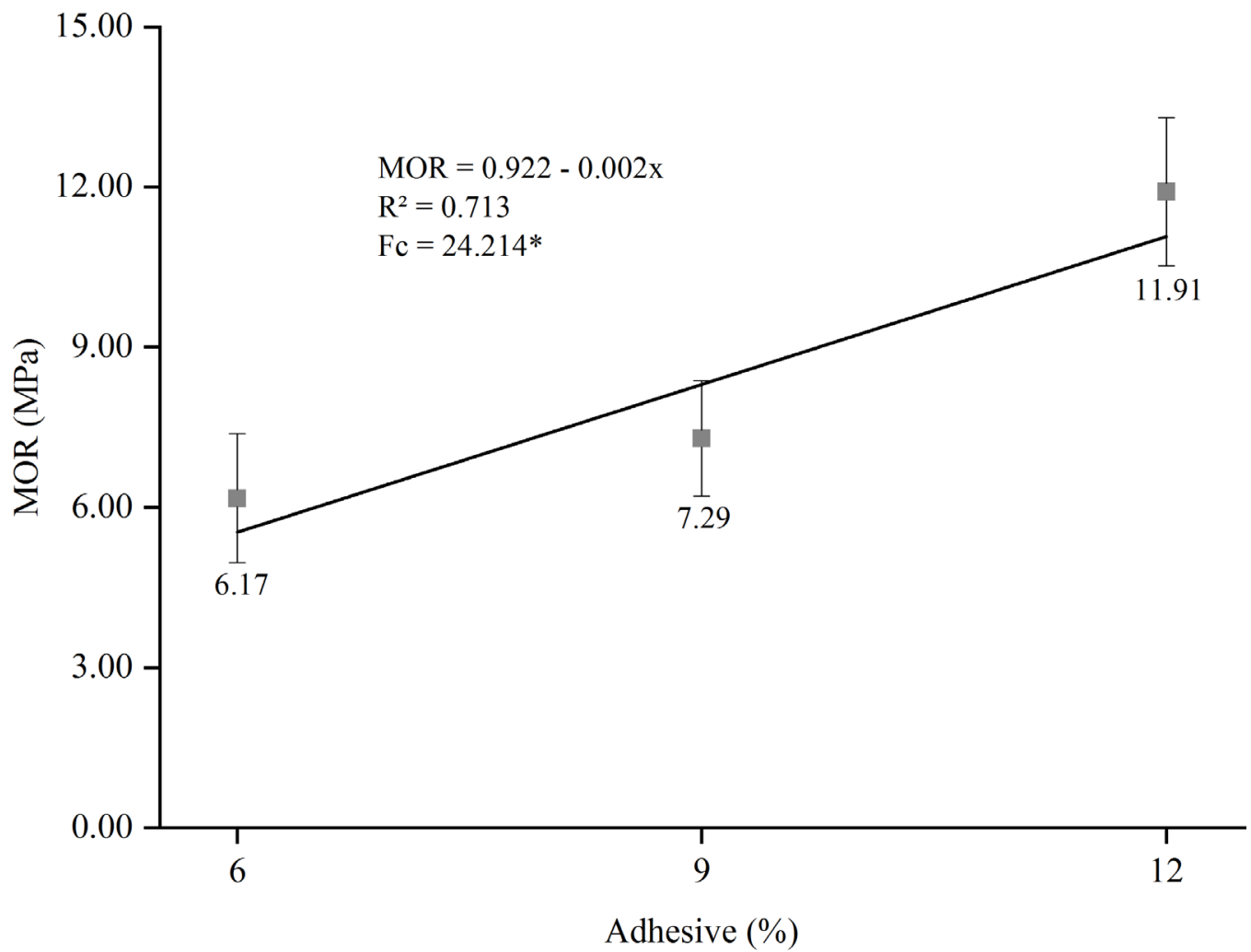

Figure 4: Modulus of rupture in static bending of particleboard where $(*)$ - significant at $5 \%$ significance level.

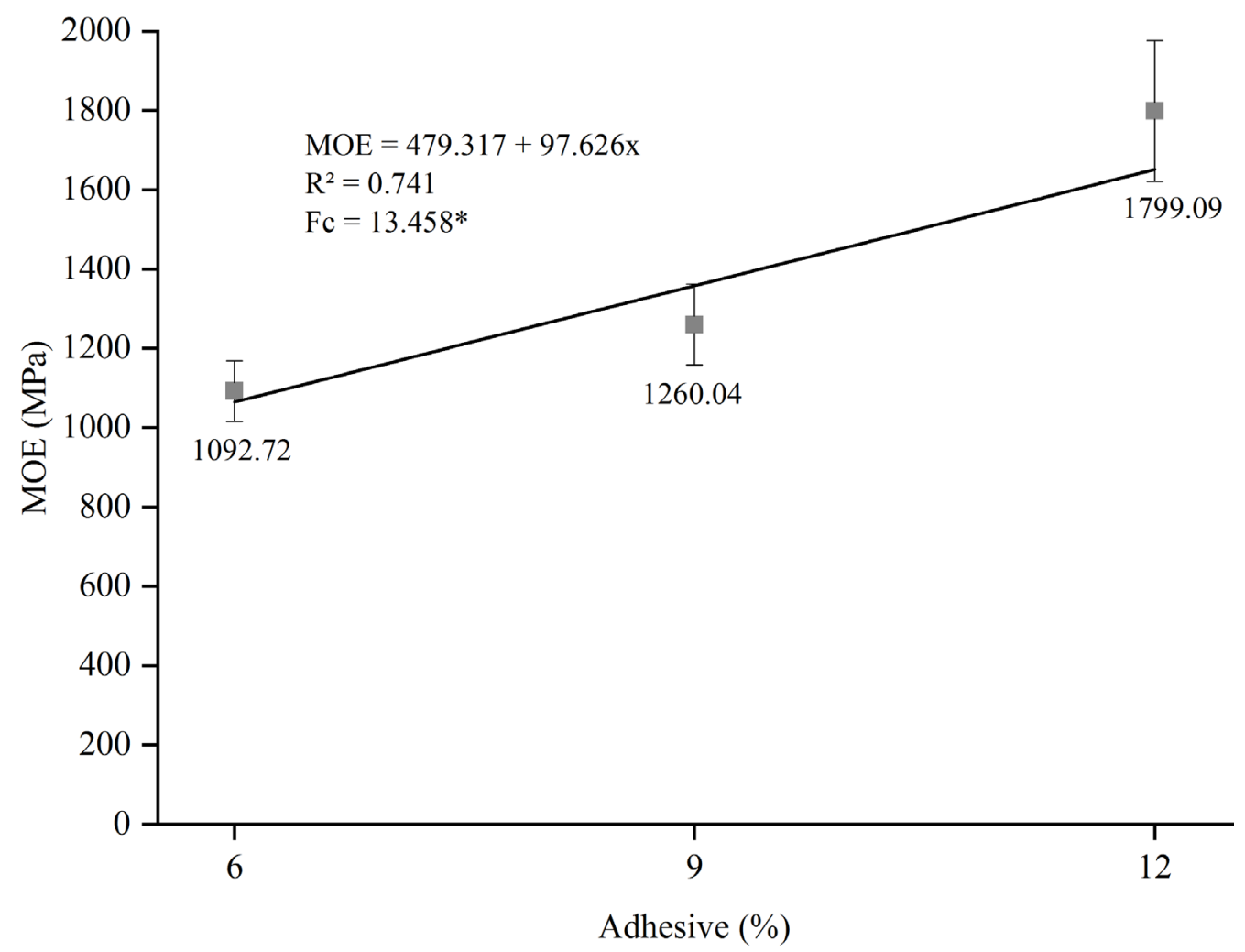

Figure 5: Modulus of elasticity in static bending of particleboards, where $(*)$ - significant at $5 \%$ significance level. 
The regression model adjusted for increasing the percentage of urea-formaldehyde adhesive for perpendicular traction values are presented in Figure 6.

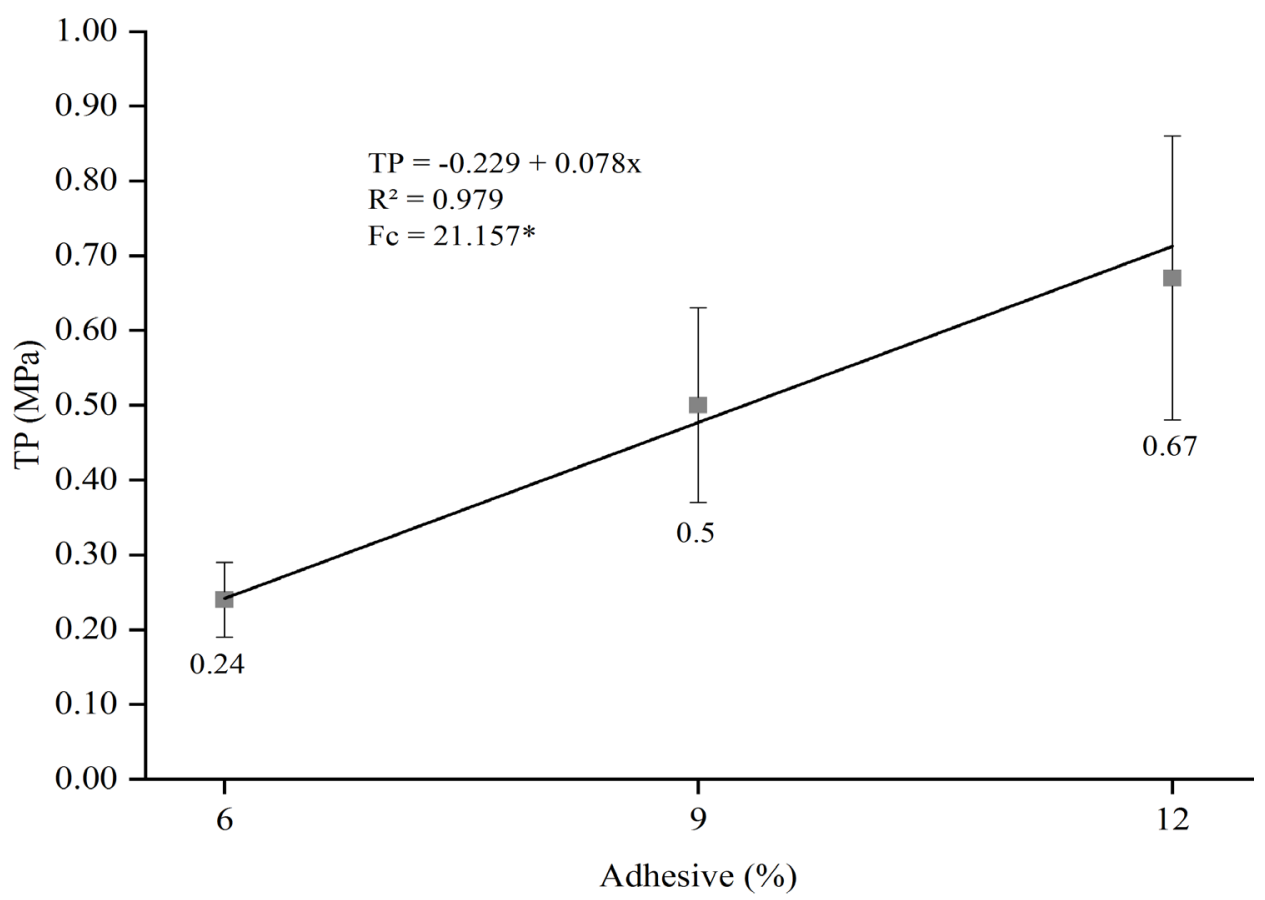

Figure 6: Relationship between adhesive percentage and perpendicular tensile strength, where $(*)$ - significant at $5 \%$ significance level.

\subsubsection{Janka Hardness and Screw Pullout}

The regression model adjusted for increasing the percentage of urea-formaldehyde adhesive for Janka hardness values is presented in Figure 7.

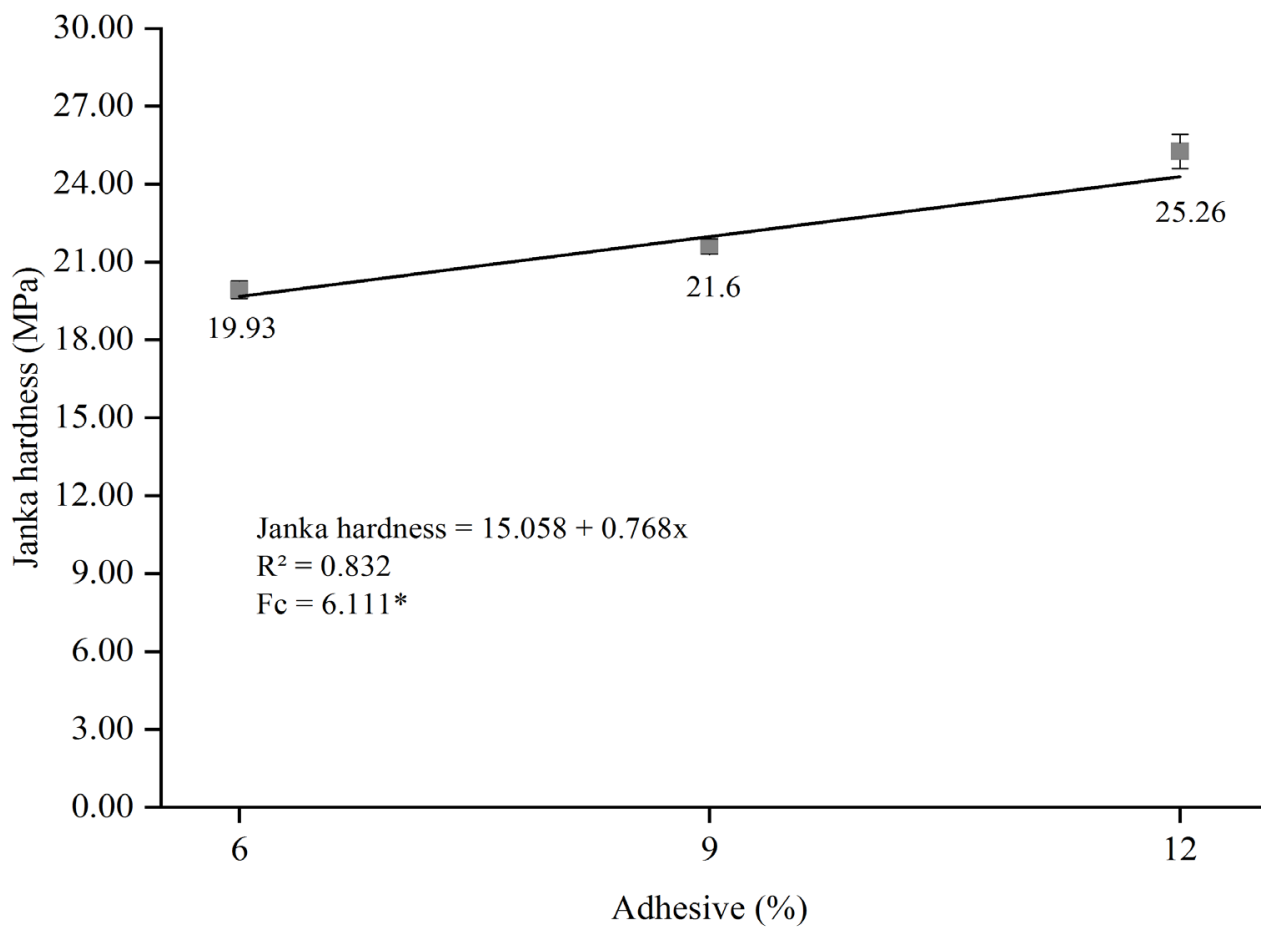

Figure 7: Relationship between adhesive percentage and Janka hardness strength, where $\left({ }^{*}\right)$ - significant at $5 \%$ significance level. 
The regression model adjusted for increasing the percentage of urea-formaldehyde adhesive for screw pullout values at face and top conditions is presented in Figure 8.

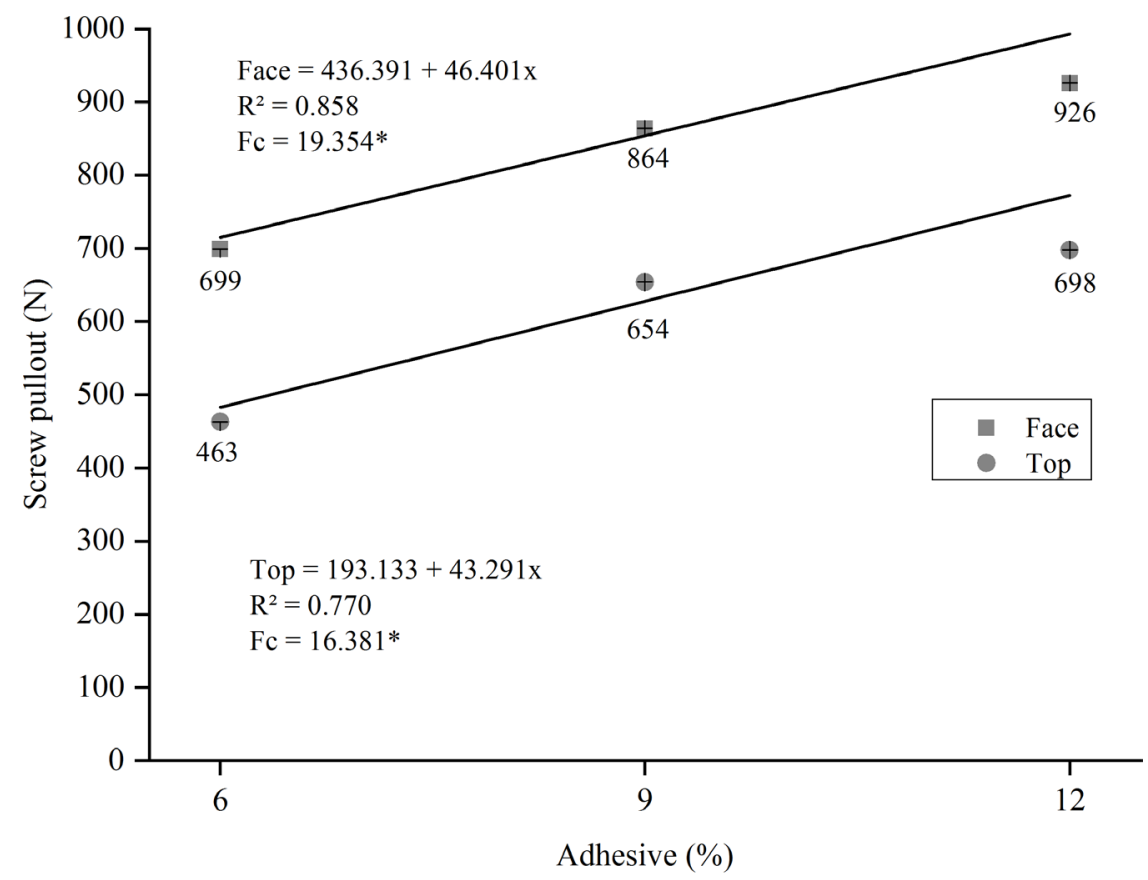

Figure 8: Relationship between adhesive percentage and screw pullout strength, where $(*)$ - significant at $5 \%$ significance level.

\section{DISCUSSION}

\subsection{Physical properties of the panels}

The values obtained for apparent density for the panels produced did not differ statistically by the Scott-Knott mean test at $5 \%$ significance. According to NBR 14810-2 [11], the panels can be classified as medium density, as they have an apparent density higher than $0.551 \mathrm{~g} . \mathrm{cm}^{-3}$. It was observed that as the adhesive content of the panels increased, they maintained their average values for apparent density. Similar behavior was observed by Rios et al. [12], whose authors observed apparent density of panels produced with different levels of urea-formaldehyde and Pinus wood ranging from 0.547 to $0.572{\mathrm{~g} . \mathrm{cm}^{-}}^{-}$ ${ }^{3}$, showing no statistically significant differences between treatments. Note that the density of the panel is related to the particle compaction rate, also depending on the mattress moisture and other factors such as specific wood mass, adhesive content and material loss during handling of particles in the steps of adhesive application, mattress formation and panel pressing [13].

For the compression ratio, the treatments did not show statistical differences as the urea-formaldehyde levels in the panels were increased, following the same behavior of apparent density. The average compression ratio values ranged from 1.217 to 1.234 for panels made with 6 and 12\% urea-formaldehyde adhesive, respectively. A lower apparent density of wood, according to several authors, implies panels with higher compression ratios $[14,15,16]$. Similar results were reported by Guimarães Junior et al. [15], Soares et al. [17] and Andrade et al. [18]. None of the panels produced were within the range of 1.3 to 1.6, considered ideal by Maloney [19] and Moslemi [20] for proper contact between wood particles and adhesive bond formation to occur. This property is a parameter of great importance in the mechanical strength of particulate boards, since panels with higher compression ratio will probably cause superior mechanical properties [18].

Moisture ranged from 8.33 to $8.44 \%$ for panels produced with different adhesive levels, below the moisture content of the climate chamber, which is $12 \%$. According to Silva et al. [21], the moisture content obtained in this work is in the range for products from reconstituted wood, lower than solid wood when exposed under similar temperature and moisture conditions. Also according to the authors, this behavior is due to different levels of hygroscopicity, caused by the reduction of particulate wood and subsequent bonding with adhesive. Another aspect that contributes to the reduction of hygroscopicity is the use of high temperatures and pressure in the final consolidation of the panel, being responsible for the partial degradation of the polyioses, in particular of the hydroxyl groups, which attribute hydrophilic character to the wood. 
The Brazilian standard NBR 14810-2 [11] stipulates moisture values between 5 and 11\%, thus, all treatments fit the cited standard.

\subsection{Panels Water absorption (WA) and Thickness swelling (TS)}

Decreased water absorption as the adhesive content has increased is related to a higher coating of the particles, causing better bonding of the particles and also providing less availability of the sorption sites for binding to the water molecules, causing the decrease of the average values of this property [22].

Similar behavior to that observed in this study was obtained by Rachtanapun et al. [23], whose results for WA after 2 and $24 \mathrm{~h}$ of water immersion decreased as the adhesive content in the panels increased. The authors working with particleboards produced with coffee residues and urea-formaldehyde adhesive found a reduction in water absorption of $4.96 \%$ and $12.30 \%$ after 2 and 24 hours of water immersion for panels made of 11.0 and $14.5 \%$ adhesive, respectively. Such phenomenon was also observed in the work of Mendes et al. [24], whose researchers evaluating the effect of ureaformaldehyde and phenol-formaldehyde adhesives on the properties of particleboards produced with sugarcane bagasse found a reduction of $57.50 \%$ and $45.70 \%$ for water absorption after 2 and $24 \mathrm{~h}$ with adhesive contents of 6 and $12 \%$, respectively.

For TS 2 and 24h of water immersion there was the same behavior observed for WA after 2 and $24 \mathrm{~h}$ water immersion. As the adhesive levels were increased, the panels showed a better dimensional stability. The increase in adhesive levels caused the panels to present a lower porosity caused by the greater amount of adhesive adhered to the particles (Figure 2). This same behavior was observed by Mendes et al. [25] working with particleboards produced from sugarcane bagasse and Eucalyptus wood and joined with three levels of urea-formaldehyde adhesive, being 6,9 and 12\%. The authors obtained a reduction from 10.89 to $5.75 \%$ for TS after $2 \mathrm{~h}$ of immersion in water, and from 22.68 to $11.99 \%$ for TS after $24 \mathrm{~h}$ of immersion in water.

Comparing the results obtained in this research with the minimum properties required for medium density particleboards according to marketing standard CS 236-66 [26], all panels met the maximum value for TS after 24h of 35\% water immersion. In relation to EN 312 [27] for thickness swelling after 24 hours of immersion in water, only the treatments containing 9 and $12 \%$ of adhesive met the $14 \%$ requirement.

\subsection{Mechanical characterization of panels}

\subsubsection{Static bending and perpendicular traction}

The average MOR values ranged from 6.17 MPa for panels made with $6 \%$ urea-formaldehyde adhesive (T1) to $11.91 \mathrm{MPa}$ for panels made with $12 \%$ urea-formaldehyde adhesive (T3), where the latter treatment presented the highest mean values, differing statistically from the other treatments. This behavior can be explained by the fact that the greater the amount of adhesive applied in the production of the panels, the better the bond between the particles, which results in greater bending strength [25]. Mendes et al. [22] observed similar behavior studying the variation of the content and type of adhesive in particleboards produced with sugarcane bagasse. Brito et al. [28] working with particleboards produced with Pinus elliottii particles and shavings combinations, found the opposite behavior. The authors observed a reduction of $15.79 \%$ for panels produced with 6 and $8 \%$ urea-formaldehyde adhesive contents.

For MOE, the average values ranged from 1092.72 MPa for panels made with $6 \%$ urea-formaldehyde adhesive (T1) to $1799.09 \mathrm{MPa}$ for panels made with $12 \%$ urea-formaldehyde adhesive (T3) with statistically different means. Brito et al. [28] found no statistically significant differences for MOE in panels produced with Pinus elliottii particles and shavings at two concentrations of urea-formaldehyde adhesive, 6 and 8\%. Rios et al. [12] also observed no effect of the adhesive content on the average MOE values for particleboards produced with Pinus patula particles Schltdl. \& Cham. Mendes et al. [22] noted increased stiffness of particleboards made from sugarcane bagasse as the adhesive content changed.

Only panels made with $12 \%$ urea-formaldehyde adhesive met the minimum requirement set by the ANSI 208.1 [29] standard of $1700 \mathrm{MPa}$ for MOE and $11 \mathrm{MPa}$ for MOR. Regarding the marketing standard CS 236-66 [26], no treatment met the minimum value of $2402.63 \mathrm{MPa}$ for MOE in medium density particleboards produced with urea-formaldehyde adhesive. Also according to the regulations, only the treatment produced with $12 \%$ of adhesive met the minimum value of $10.98 \mathrm{MPa}$ for MOR.

For the perpendicular traction property, it was observed that there was a statistically significant difference for all studied treatments. As there was a greater adhesive coverage on the particles and consequently better adhesion, the panels presented better tensile strength by the perpendicular tensile test. Panels made with $12 \%$ urea-formaldehyde adhesive had a $179.16 \%$ gain in perpendicular tensile strength compared to panels made with $6 \%$ of the same adhesive. Similar behavior 
was observed by Mendes et al. [25], finding results for perpendicular traction of 5.24 and $8.51 \mathrm{MPa}$ for particleboards produced with 6 and $12 \%$ urea-formaldehyde adhesive, respectively. This trend was also observed by Mendes et al. [22], where the authors noted an increase from $0.55 \mathrm{MPa}$ to $0.84 \mathrm{MPa}$ for medium density particleboards produced with ureaformaldehyde adhesive and a combination of Pinus spp wood with sugarcane bagasse particles. The increase in average perpendicular tensile values may be attributed to the higher adhesive availability per unit area of particles [30].

According to EN 312 [27], only 9 and $12 \%$ adhesive content treatments met the minimum requirement of $0.35 \mathrm{MPa}$. The same was true for marketing standard CS 236-66 [26], which stipulates minimum perpendicular tensile strength values for medium density particleboards of $0.48 \mathrm{MPa}$, where also only panels produced with 9 and $12 \%$ urea-formaldehyde adhesive complied with this standard.

\subsubsection{Janka Hardness and Screw Pullout}

Analyzing Figure 7 presented for Janka hardness, it was observed that there was a statistically significant difference between the evaluated treatments. Results similar to those observed in this study were verified by Baldin et al. [31] working with particleboards produced with different proportions of wood and annoni grass, obtaining an average value of $19.93 \mathrm{MPa}$ for panels produced with urea-formaldehyde adhesive and 24.94 MPa for panels produced with tannin adhesive. Therefore, the results found in this work are close to those observed in the literature.

ANSI marketing standard A 208.1 [29] establishes for Janka hardness a minimum value of 22,7 MPa in particleboards, so only particleboards produced with $12 \%$ of urea-formaldehyde adhesive has reached the minimum value set by the standard.

The results of the screw pullout resistance test indicated that there was a statistically significant difference between the treatments in the two evaluated conditions: face and top. The results obtained for the three evaluated treatments are close to those of Rios et al. [12] for both test conditions. The authors obtained mean screw pullout values of 778.31 and $540.68 \mathrm{MPa}$ for the face and top conditions, respectively. In relation to the study by Cunha et al. [13], the mean values found in this study are below those of the authors, who obtained screw pullout resistance at the top condition of 1163.93 $\mathrm{MPa}$ and $1321.06 \mathrm{MPa}$ for the face condition.

None of the treatments studied met the minimum requirements of NBR 14810-2 [11], which establishes minimum thresholds of $1020 \mathrm{~N}$ for surface pullout and $800 \mathrm{~N}$ for top. Regarding the American standard ANSI A 208.1 [29], which fixes $900 \mathrm{~N}$ for surface and $800 \mathrm{~N}$ for top regardless of the direction of application, only the panels produced with $12 \%$ adhesive complied with the above mentioned standard. According to Cunha et al. [13], the low values found for this property can be attributed to the low density of the panels. High density particleboards have better screw pullout values than medium and low density panels.

\section{CONCLUSIONS}

For the physical properties, the increase of the adhesive content did not change the average apparent density values as well as the compression ratio. Regarding moisture, all treatments fall within the standard NBR 14810-2 [11]. There was a significant decrease in values for WA and TS properties after 2 and 24h, when the adhesive content was increased, in which all treatments met the CS 236-66 [26] standard for TS at 24h.

Regarding mechanical properties, there was a 93\% gain for MOR property, $64 \%$ for MOE property and $179 \%$ for perpendicular traction with increasing adhesive content from 6 to $12 \%$. Only the treatment with $12 \%$ adhesive content met the minimum value for MOR. For perpendicular traction only the panels produced with 9 and $12 \%$ adhesive content met this standard. For Janka hardness the treatments with 9 and 12\% adhesive content had the highest average values, 21.6 and 25.26 MPa, where only the panel with $12 \%$ adhesive reached the ANSI A 208.1 standard [29]. The results of the screw pullout strenght test indicated that only panels produced with $12 \%$ adhesive met the American standard ANSI A 208.1 [29], which fixes $900 \mathrm{~N}$ for surface, compared to the Brazilian standard NBR 14810-2 [11] none of the treatments met such normative.

\section{BIBLIOGRAPHY}

[1] WEBER, C., IWAKIRI, S., "Utilization of waste of plywood, MDF and MDP for the production of particleboards", Ciencia Florestal, v. 25, n. 2, pp. 405-413, 2015.

[2] FAGUNDES, H.A.V., Diagnosis of lumber production and waste generation from wood processing of planted forests in Rio Grande do Sul, Dissertation (Master in Civil Engineering) - Federal University of Rio Grande do Sul, Porto Alegre, 2003. 
[3] IBÁ - BRAZILIAN TREE INDUSTRY. Yearbook 2017: base year 2017. São Paulo: Ibá, 2017. 80 p.

[4] RIOS, P.D., Technological characterization and production of boards of the cork from Kielmeyera coriacea Mart. (pausanto), Dissertation (Master in Forest engineering) - Federal University of Lavras, Lavras, 2007.

[5] MENDES, R.F., BALEEIRO, N.S., MENDES, L.M., SCATOLINO, M.V., OLIVEIRA, S.L., PROTÁSIO, T.P., "Physical and mechanical properties of particleboard produced with Eucalyptus grandis wood in different radial positions", Scientia Forestalis, v. 41, n. 99, pp. 417-423, set. 2013.

[6] LOPES, T.A., VILELA, A.P., SILVA, D.W., MENDES, R.F., MENDES, L.M., "High density particleboards produced with wood shavings", In: XV EBRAMEM - Encontro Brasileiro em Madeiras e Estruturas de Madeira, 2016, Curitiba - PR. XV EBRAMEM - Encontro Brasileiro em Madeiras e Estruturas de Madeira, 2016.

[7] AMERICAN SOCIETY FOR TESTING AND MATERIALS. Annual book of ASTM: D-1037: Standard methods of evaluating properties of wood-base fiber and particles materials. Philladelphia, 2012. 31p.

[8] DEUTSCHES INSTITUT FUR NORMUNG. DIN 52362: Testing of wood particleboards, bending test, determination of bending strength. Berlin, 1982. $40 \mathrm{p}$.

[9] BRAZILIAN ASSOCIATION OF TECHNICAL STANDARDS. NBR 14810: Wood particleboard Part 3: Test methods. 2006. $51 \mathrm{p}$.

[10] AMERICAN SOCIETY FOR TESTING AND MATERIALS. ASTM D 143-94: methods of testing of small clear specimens. [S.1.], 1996.

[11] BRAZILIAN ASSOCIATION OF TECHNICAL STANDARDS. NBR 14810: Medium density particleboards Part 2 : Requirements and test methods. 2018.71 p.

[12] RIOS, P.D., PEREIRA, G.F., VIEIRA, H.C., GRUBERT, W., CUNHA, A.B., BRAND, M.A., “Pinus patula Schltdl. \& Cham wood potential evaluation for particleboard production”, Scientia Forestalis, v. 44, n. 110, pp. 497-508, 2016.

[13] CUNHA, A.B., LONGO, B.L., RODRIGUES, A.A., BREHMER, D.R., "Particleboard manufacture from Eucalyptus benthamii, Eucalyptus dunnii e Eucalyptus grandis", Scientia Forestalis, v, 42, n. 102, pp. 259-267, 2014.

[14] SCATOLINO, M.V., SILVA, D.W., MENDES, R.F., MENDES, L.M., "Use of maize cob for production of particleboard", Ciência e Agrotecnologia, v. 37, n. 4, pp. 330-337, 2013.

[15] GUIMARÃES JUNIOR, J.B., XAVIER, M.M., SANTOS, T.S., PROTÁSIO, T.P., MENDES, R.F., MENDES, L.M., "Addition of sorghum culture waste in eucalyptus particleboard", Pesquisa Florestal Brasileira, v. 36, n. 88, pp. 435- 442, 2016.

[16] SCATOlinO, M.V., COSTA, A.O., GUIMARÃES JUNIOR, J.B., PROTÁSIO, T.P., MENDES, R.F., MENDES, L.M., "Eucalyptus wood and coffee parchment for particleboard production: physical and mechanical properties", Ciência e Agrotecnologia, v. 41, n. 2, pp. 139-146, 2017.

[17] SOARES, S.S., GUIMARÃES JÚNIOR, J.B., MENDES, L.M., MENDES, R.F., PROTÁSIO, T.P., LISBOA, F.J.N., "Valorization of sugarcane bagasse for production of low density particleboard", Brazilian Journal of Wood Science, v. 8, n. 2, pp. 64-73, 2017.

[18] ANDRADE, L.M.F., SCATOLINO, M.V., FARIA, D.L., CÉSAR, A.A., MENDES, L.M., GUIMARÃES JÚNIOR, J.B., "Inclusion of cellulose pulping waste for production of medium density particleboard", Scientia Forestalis, v. 46, n. $120,2018$.

[19] MALONEY, T. M. Modern particleboard \& dry-process fiberboard manufacturing. Backbeat, 1993.

[20] MOSLEMI, A.A. Particleboard. Illinois: Southern Illinois University Press, 1974. 244p.

[21] SILVA, G.A., MENDES, L.M., CALEGÁRIO, N., MORI, F.A., SILVA, J.R.M., SANTOS, I.F., "Estimate of the equilibrium moisture content of wood panels", Scientia Forestalis, n. 70, pp. 23-29, 2006.

[22] MENDES, R.F., MENDES, L.M., GUIMARÃES JÚNIOR, J.B., SANTOS, R.C., CÉSAR, A.A.S., “Association effect of sugar cane bagasse, type and levels of adhesive on particleboard production”, Ciência Florestal, v. 22, n. 1, pp. 161-170, 2012.

[23] RACHTANAPUN, P., SATTAYARAK, T., KETSAMAK, N., "Correlation of density and properties of particleboard from coffee waste with urea-formaldehyde and polymeric methylene diphenyl diisocyanates", Journal of Composite Materials, v. 46, n. 15, pp. 1839-1850, 2012.

[24] MENDES, R.F., MENDES, L.M., GUIMARÃES JÚNIOR, J.B., SANTOS, R.C., BUFALINO, L., “The adhesive 
effect on the properties of particleboards made from sugar cane bagasse generated in the distiller", Revista de Ciências Agrárias, v. 32, n. 2, pp. 209-218, 2009.

[25] MENDES, R.F., MENDES, L.M., ABRANCHES, R.A.S., SANTOS, R.C., GUIMARÃES JÚNIOR, J.B., "Particleboards produced with sugar cane bagasse and Eucalyptus wood", Scientia Forestalis, v. 38, n. 86, pp. 285-295, 2010.

[26] CS - COMMERCIAL STANDARD. CS 236-66: mat formed wood particleboard. [S.1.], 1968.

[27] EUROPEAN STANDARD. EN 312: particleboards: specifications. British Standard Institution, London, 2003. 22p.

[28] BRITO, E.O., SAMPAIO, L.C., OLIVEIRA, J.N., BATISTA, D.C., "Particleboard using particles from logs and planner shavings", Scientia Forestalis, n. 72, pp. 17-21, 2006.

[29] AMERICAN NATIONAL STANDARD INSTITUTE. Mat-formed wood particleboard: specification ANSI A 208.1. Leesburg: Composite Panel Association, 2009. 13 p.9

[30] SANTOS, R.C., MENDES, L.M., MORI, F.A., MENDES, R.F., "Particleboard produced from residues generated after the extraction of candeia wood oil (Eremanthus erythropappus)", Scientia Forestalis, Piracicaba, v. 37, n. 84, pp. 437-446, 2009.

[31] BALDIN, T., SILVEIRA, A.G., VIDRANO, B.R.A., CANCIAN, L.C., SPATT, L.L., HASELEIN, C.R., "Quality of particleboard produced with different proportions of wood and capim-annoni”, Revista Brasileira de Ciências Agrárias, v. 11, n. 3, pp. 230-237, 2016.

\section{ORCID}

Douglas Lamounier Faria Thamirys Andrade Lopes Lourival Marin Mendes José Benedito Guimarães Júnior https://orcid.org/0000-0002-5405-8430 https://orcid.org/0000-0002-2782-8604

https://orcid.org/0000-0001-8713-405X https://orcid.org/0000-0002-9066-1069 